\title{
Insights from paleomicrobiology into the indigenous peoples of pre-colonial America - A Review
}

\author{
Millie I Darling1, Helen D Donoghue ${ }^{1,2 /+}$ \\ 'Division of Biosciences ${ }^{2}$ Division of Infection and Immunity, Centre for Clinical Microbiology, University College London, London, UK
}

This review investigates ancient infectious diseases in the Americas dated to the pre-colonial period and considers what these findings can tell us about the history of the indigenous peoples of the Americas. It gives an overview, but focuses on four microbial pathogens from this period: Helicobacter pylori, Mycobacterium tuberculosis, Trypanosoma cruzi and Coccidioides immitis, which cause stomach ulceration and gastric cancer, tuberculosis, Chagas disease and valley fever, respectively. These pathogens were selected as $\mathrm{H}$. pylori can give insight into ancient human migrations into the Americas, M. tuberculosis is associated with population density and urban development, T. cruzi can elucidate human living conditions and $\mathrm{C}$. immitis can indicate agricultural development. A range of methods are used to diagnose infectious disease in ancient human remains, with DNA analysis by polymerase chain reaction one of the most reliable, provided strict precautions are taken against cross contamination. The review concludes with a brief summary of the changes that took place after European exploration and colonisation.

Key words: ancient DNA - Helicobacter pylori - Mycobacterium tuberculosis - Trypanosoma cruzi - Coccidioides immitis

Infectious disease is the presence and growth of pathogenic biological agents within a host, usually resulting in a clinically evident illness. Pathogenic biological agents include bacteria, viruses, fungi and parasites. Many pathogens have a very long history with the human species, with several having an association with primates long predating the evolution of Homo sapiens. Humans and pathogens have therefore evolved together and had a great influence on each other. Because human and pathogen history is so intertwined, much fascinating information can be learnt about ancient humans by studying ancient pathogens.

For thousands of years North and South America have been home to different human populations. Prior to European contact in 1492, these populations lived in the Americas effectively isolated from the rest of the world. This resulted in very different societies and human infectious diseases developing in the Eastern and Western Hemispheres. There are written records of many of the past human infectious diseases of Eurasia, but due to the destruction by European colonialists, it is not known if there were ever any local records of past human infectious diseases of the Americas. To investigate these diseases we therefore have to investigate ancient human remains through paleopathological and, more recently, paleomicrobiological studies. Paleomicrobiology is an interdisciplinary subject that necessarily overlaps with biology, archaeology, history and anthropology to investigate past infectious diseases (Donoghue 2008). Here, paleomicrobiological studies of the Americas are reviewed to determine what they can tell us about the

doi: $10.1590 / 0074-0276140589$

+ Corresponding author: h.donoghue@ucl.ac.uk

Received 19 December 2013

Accepted 7 February 2014 pre-colonial history of the indigenous peoples of the Americas. Many earlier authors have explored this topic (Patrucco et al. 1983, Verano 1997, Ramenofsky et al. 2003, Gerszten et al. 2012, Anastasiou \& Mitchell 2013, Frías et al. 2013, Harper \& Armelagos 2013) and have laid the foundation for this review.

Infectious disease transmission occurs between humans in a variety of ways, ranging from inhalation of infected moisture droplets, faecal-oral transmission, infection of wounds from the environment, to transmission via an insect vector. Population density, association with animals, proximity of living areas to water sources and human waste, trade links, genetic susceptibility and the use of agricultural methods such as irrigation influence the infectious diseases that occur in the human population. For example, a disease such as tuberculosis that is dependent on respiratory transmission needs a large dense human population to be successfully maintained and transmitted.

It is generally believed that humans first migrated to the Americas approximately 13,000 years ago via the Bering Land Bridge (Beringia) while sea levels were significantly low. The humans who first arrived on the landmass that came to be known as North and South America were battling against infectious diseases they brought with them from Asia and those they acquired in the Americas. The aim is not to discuss in depth every pathogen that plagued the pre-colonial Americas, so this review uses selected infectious diseases as examples of the different relationships between humans and their environment. The first of two sections discusses "heirloom" infectious diseases brought to the Americas by the humans that first migrated there and focuses on two selected pathogens, Helicobacter pylori and Mycobacterium tuberculosis. The second section discusses diseases associated with the local environment, based on two pathogens, Trypanosoma cruzi and Coccidioides immitis, that began infecting humans after they settled in the Americas, causing "souvenir" infectious diseases (Kliks 1990). 
Paleomicrobiological methods - An important method to investigate ancient infectious diseases is the analysis of microbial ancient DNA (aDNA) by the polymerase chain reaction (PCR). PCR revolutionised paleomicrobiological research because it enables trace amounts of fragmented microbial aDNA to be identified and amplified. Thermal cycling is used to amplify aDNA. DNA polymerase and primers - short oligonucleotides that flank a specific target locus in the DNA of the pathogen being investigated - are the basis of the method. Microbial aDNA is only preserved under suitable environmental conditions such as low temperatures, dryness and absence of sunlight (Donoghue 2008).

Initially, bacterial pathogens were investigated using PCR targets present as multiple copies in every cell. The same approach can be used for eukaryotic pathogens, such as flagellated protozoa, where the kinetoplast provides an excellent target region (Aufderheide et al. 2004). Other studies examine nuclear or mitochondrial DNA. As PCR is such a sensitive technique there is great danger of contamination by modern DNA either from the site or the laboratory. It is therefore essential to use procedures to prevent contamination (Donoghue 2009) including wearing protective clothing, physical isolation of the work area, removal of the surface layer of samples, consideration of past studies that have occurred in the laboratory and the use of negative control amplifications to detect contamination. Results should be reproducible in other laboratories using the same contamination control procedures.

Today, next generation sequencing, or whole genome sequencing, reduce the risk of contamination, as there is no DNA amplification (Donoghue 2013). Extracted DNA is fragmented, end-repaired and tagged, prior to analysis by high throughput sequencers. When analysing aDNA, DNA fragment size gating can eliminate any contaminating modern DNA. The use of magnetic beads or microarrays coated with single-stranded DNA from a target genome can enrich aDNA recovery. The resulting sequences are aligned and bioinformatics analysis used to identify all the genomes present in a sample.

The samples for paleomicrobiological analyses can come from many different locations in ancient human remains, mineralised or mummified. Microbial aDNA can occur in the dental pulp of teeth, bone, mummified tissues (Drancourt \& Raoult 2005) or coprolites. Bodies may be mummified naturally or by human intervention. As mentioned by Swanston et al. (2011), naturally mummified individuals are often more suitable for bacterial DNA studies because the absence of any embalming processes leaves the local environment in the tissues unchanged. Coprolites are fossilised faeces that are useful sources of pathogen aDNA, especially for investigations of intestinal parasites (Araújo et al. 2011).

The mycobacteria, including the M. tuberculosis complex, have some unique features that facilitate the persistence of their aDNA. These microbes have DNA with a high proportion of guanine and cytosine that increases its stability and thick lipid-rich cell walls. The bacterial cell walls protect the microbial DNA from the lytic enzymes of the host cell when undergoing autolysis or necrosis. Both these features enable the direct detection and characterisation of aDNA and lipid biomarkers of M. tuberculosis in ancient specimens. Indeed, the use of whole genome sequencing has confirmed that M. tuberculosis aDNA is better preserved than human aDNA in the same specimens (Chan et al. 2013). Therefore, information can sometimes be gained from human remains based on the infecting $M$. tuberculosis aDNA rather than host aDNA.

Tran et al. (2011) described the variety of methods to diagnose ancient disease using techniques other than the analysis of aDNA via PCR. Biomolecules such as mycolic acids (of mycobacteria) and proteins can be detected in ancient specimens using immunohistochemistry, immunochromatography and ELISA techniques. Protein detection by mass spectroscopy and immuno-PCR are other potentially useful techniques. As with DNA analysis by PCR, strict protocols must be followed to avoid contamination and ensure authenticity of data.

The direct observation of ancient human material remains an important technique to diagnose ancient infectious disease, but was especially so before the invention of molecular methods. Observations include the direct detection of parasites in human remains or the paleopathology caused by the presence of the pathogen. For example, a pre-Columbian mummy of a young man in southern Peru had numerous granulomatous lesions and vesicles on his skin. Giemsa staining and microscopy showed typical clumps of bacilli with morphology similar to Bartonella bacilliformis, the cause of Carrión's disease, spread by sandflies, that results in acute fatal anaemia or a condition known as verruga - characterised by wart-like lesions (Allison et al. 1974a). Many pathogens, including M. tuberculosis, trigger visible skeletal lesions in human remains and such material was used in the first study to diagnose ancient tuberculosis by the detection of pathogenic bacterial aDNA (Spigelman \& Lemma 1993). Skeletal observations are essential when DNA analysis and other biomolecular methods are inconclusive, but are often problematic because different diseases can cause similar skeletal changes. Therefore paleopathology alone may give insufficient evidence to diagnose a disease. Ideally, morphological observation and biomolecular methods should be used to complement each other and strengthen the evidence that a particular pathogen was present. Dating of ancient specimens is a very important part of paleomicrobiological research. A variety of methods are used, including the investigation of artefacts associated with the remains, the archaeological and architectural features of the surrounding area, the stratigraphic provenance of the remains and radiocarbon dating of the skeletons themselves and associated organic matter.

Heirloom human infectious diseases in the Americas This section discusses human infectious diseases brought to the Americas with the humans that first migrated there. Heirloom human infectious diseases are caused by bacteria, viruses or parasites (Araújo \& Ferreira 2000), which have evolved with humans in Africa, Europe and Asia. There are many studies and reviews of the paleoparasitology of the Americas, including protozoa (Ortega \& Bonavia 2003, Costa et al. 2009), roundworms (Araújo et al. 2008a, Leles et al. 2008), pinworms (Iñiguez et al. 2006), fleas and lice (Raoult et al. 2008, Dittmar 2009). 
However, there are far fewer reports of viral (Gentry et al. 1988, Li et al. 1999) or bacterial infections. Arriaza et al. (2013) used the distribution of head lice (Pediculus humanus capitis) in archaic mummies from northern Chile as a bioindicator of cultural behaviour, as the lice are associated with crowded living conditions. The human head louse has also given insights into migration and the human colonisation of the New World (Ascunce et al. 2013). Wirth et al. (2005) reviewed the association of various microbes with their host and examined the most appropriate candidates that can act as markers to enable human migrations to be tracked. They concluded that the best example was $H$. pylori. Recent advances in understanding the genomics and genetic lineages of $H$. pylori and another pathogen with close links to human lineages, M. tuberculosis, are highlighted below.

H. pylori - Human migration into the Americas - $H$. pylori is a Gram-negative bacterium. It can be used as a marker of prehistoric human migrations because it has been associated with humans throughout human evolution. Indeed, bacteria related to $H$. pylori are found in non-human primates and other mammals, indicating the long history of co-evolution with mammalian species. Due to this long association with H. pylori, human gastric physiology has evolved so that the presence of the bacterium is advantageous in some ways and may protect the human stomach from other bacterial infections (Atherton 2006). Human transmission of the bacterium is not well understood, but is believed to most often occur between humans via the oral-oral or the faecal-oral route.

A study by Linz et al. (2007) using a large dataset of modern $H$. pylori DNA sequences has revealed that, as with humans, the genetic diversity of $H$. pylori decreases with geographical distance from East Africa. This indicates that the first humans, who evolved in East Africa, were infected with $H$. pylori prior to their migrations out of this area 58,000 years ago. The findings of Falush et al. (2003) support this research, as they showed that bacterial sequences of one virulence-associated gene $(\mathrm{vacA})$ and fragments of seven housekeeping genes differ according to the continent in which they are found and the human population with which they are associated.

Ancient strains of $H$. pylori have been identified in human remains discovered in the Americas. The first discovery, in a mummified individual from the funeral cave of La Ventana in Chihuahua State desert in Mexico, dated to approximately $1350 \mathrm{AD}$ (Castillo-Rojas et al. 2008). Pre-Columbian H. pylori was confirmed by $16 \mathrm{~S} r R N A$ DNA sequences. The second discovery, by Swanston et al. (2011), was based on a Kwäday Dän Ts'ìnchi individual found in the Samuel Glacier in Tatshenshini-Alsek Park in British Columbia in Canada, from the late XVII and mid-XIX centuries. The $H$. pylori DNA amplified from the stomach of the Kwäday Dän Ts'ìnchi individual contained a $v a c A \mathrm{~m} 2 \mathrm{a} / \mathrm{m} 1 \mathrm{~d}$ allele associated with indigenous American strains, but also a vacA s2 allele, rare in Asian strains, but commonly associated with European strains. The Kwäday Dän Ts'ìnchi individual was radiocarbon dated to approximately 1670-1850 AD, a time after European contact with the Americas. Therefore the most likely reason that the European and indigenous American regions are present in bacteria amplified from this indi- vidual is because there were Europeans present in Canada during the individual's lifetime and the H. pylori bacteria in the Kwäday Dän Ts'ìnchi individual are therefore hybrids. Both these $H$. pylori findings in these historical individuals therefore support the theory that humans first migrated to the Americas from Asia. The Mexican mummy was dated to approximately $1350 \mathrm{AD}$, a time prior to European contact with the Americas, so the evidence that humans first migrated to the Americas from Asia is especially strong from this source.

Yamaoka et al. (2002) analysed modern strains of $H$. pylori associated with indigenous peoples of the Americas, based on variations in the alleles vacA, cagA - part of the cag pathogenicity island in the $H$. pylori genome and the right end of the cag pathogenicity island. They found that some native Colombian and Alaskan strains possessed novel vacA and/or cagA gene structures and were more closely related to East Asian than to nonAsian H. pylori. Also, some native Alaskan strains appear to have originated in Central Asia and to have arrived after strains found in South America suggesting that $H$. pylori crossed the Bering Strait from Asia to the New World at different times.

In a study of another modern population, a group of Amerindian subjects from Amazonia, East Asian H. pylori genotypes were present for each of the loci examined, but were absent in a mestizo population from Caracas. These findings provide evidence that $H$. pylori has been present in humans at least since ancestors of Amerindians migrated from Asia more than 11,000 years ago (Ghose et al. 2002). A more recent study of modern strains from Mexico (Camorlinga-Ponce et al. 2011) showed that Mexican indigenous people with Amerindian markers are colonised with $H$. pylori showing an admixture of Asian, European and African strains in genes known to interact with the gastric mucosa. In addition, evidence was found of novel Amerindian $\operatorname{cag} A$ and $v a c A$ alleles in indigenous groups of North and South America.

The most obvious route for human migration to the Americas from Asia was via Beringia - the Bering Land Bridge that existed for hundreds of years while sea levels were low, approximately 13,000 years ago. However, Araújo et al. (2008b) suggest that this cannot have been the only way that humans first entered the pre-Columbian Americas. Abundant evidence of parasites such as hookworm (Ancylostoma duodenale, Necator americanus), whipworm (Trichuris trichiura) and threadworm (Strongyloides stercoralis) has been identified across the Americas (Allison et al. 1974b, Patrucco et al. 1983, Araújo et al. 2011, Jiménez et al. 2012). These parasites are host specific so must have entered the Americas with migrating humans. However, their spread into the New World cannot be explained easily by a migration through Beringia. These parasites need warm moist soils to develop in and to this day do not occur in traditional populations in the Arctic region (Araújo et al. 2011). None of these parasites could have survived the freezing conditions of the Siberia-Alaska region that humans would have had to pass through if reaching the Americas via the Bering Land Bridge. Araújo et al. (2008b) therefore infer that these findings suggest alternative migration routes into the Americas and suggest that some humans 
(and their parasitic stowaways) arrived via transpacific migration in boats or by coastal migration, possibly through the sub-Arctic region. This area requires further research to understand how this may have happened.

M. tuberculosis - Dense human populations - M. tuberculosis is a bacterium found across the world. There are a group of closely related pathogenic bacteria known collectively as the M. tuberculosis complex. The principle cause of human tuberculosis is $M$. tuberculosis sensu stricto, whereas Mycobacterium bovis is the principle cause of tuberculosis in bovids and other animals. M. tuberculosis and $M$. bovis evolved from a common ancestor (Gutierrez et al. 2005) and genomics indicate that ancestral mycobacteria probably began infecting early hominids in East Africa approximately three million years ago. Modern analyses of M. tuberculosis reveal that it is an extremely diverse bacterium and appears to have co-evolved with its human hosts (Gagneux et al. 2006, Hershberg et al. 2008). Therefore, M. tuberculosis, like H. pylori, has been associated with humans for so long its diversity is linked to human migratory history and different strains of the bacterium are associated with different regions of the world.

Tuberculosis was first identified in humans in the precolonial Americas, using morphological evidence in a mummified child, dated to approximately $700 \mathrm{AD}$, from the Nazca culture of Southern Peru (Allison et al. 1973, Gerszten et al. 2012). This mummy had bone pathology suggestive of tuberculosis and microscopic evidence of acid-alcohol resistant bacilli. Subsequent PCR studies have identified ancient $M$. tuberculosis complex DNA in pre-colonial human remains, thereby confirming its presence prior to European contact. Salo et al. (1994) were the first to do so using PCR to demonstrate M. tuberculosis complex DNA from a hilar lymph node lesion in a 1,000 year-old naturally mummified body from southern Peru. Arriaza et al. (1995) successfully used PCR to diagnose tuberculosis in ancient human remains in Chile dated to approximately $1040 \mathrm{AD}$. The $M$. tuberculosis complex was also detected in North American material from early XI century Mississippi and XV century Canada (Braun et al. 1998). These and other studies (i Prat \& de Souza 2003) confirm that the M. tuberculosis complex was present in the Americas prior to 1492. An early suggestion that these infections were caused by $M$. bovis (Daniel 2000) was thrown into doubt by the findings of Rothschild et al. (2001), who used PCR to detect M. tuberculosis complex aDNA from a 17,000 year-old Pleistocene bison metacarpal from Natural Trap Cave, Wyoming. Attempts at typing the aDNA fragments led to the conclusion that the bison tuberculosis was clearly distinct from modern $M$. bovis, but resembled human $M$. tuberculosis or Mycobacterium africanum.

The doubts about the existence of tuberculosis in the pre-colonial Americas arose largely because of the great tuberculosis epidemics that raged among indigenous peoples of the Americas after European contact (Wilbur $\&$ Buikstra 2006). Such epidemics suggested that these populations had not been exposed to the disease before. It is now suggested that the tuberculosis epidemics that raged among indigenous populations after European contact occurred because of exposure to more virulent European strains of the disease. There is accumulating evidence that ancestral $M$. tuberculosis lineages are less virulent (Gagneux 2012) and it is intriguing to speculate that this also applied to the indigenous tuberculosis in the Americas. However, its genetic characterisation is only now about to be published (Bos et al. 2014).

It is interesting to discuss the social structure of the ancient human populations in which M. tuberculosis complex DNA has been discovered. The oldest known cases of M. tuberculosis sensu stricto were identified by aDNA and skeletal evidence in human remains recovered from a 9,000 year-old Neolithic settlement in the Eastern Mediterranean (Hershkovitz et al. 2008). This settlement is one of the earliest known human villages with evidence of animal domestication and agriculture. The shift from gatherer-hunters to settled farming communities in the Neolithic period meant that infectious diseases such as tuberculosis that are associated with denser human populations became endemic in agricultural populations from this period onwards. Across the world, the presence of tuberculosis often correlates with the existence of animal domestication because domesticated animals are needed to maintain large human populations and these large populations thereby maintain the tuberculosis. It was previously believed that this correlation existed because humans caught the disease from their animals, but this cannot be the case as $M$. tuberculosis is genetically more ancestral than M. bovis (Brosch et al. 2002).

The Chiribaya population, in which Salo et al. (1994) found tuberculosis, was agricultural and occupied the Osmore Valley of Peru between approximately 10001300 AD. A tuberculosis-like disease was present in prehistoric populations from Northwest Argentina in the XIV-XV centuries. Six of 70 excavated individuals provided evidence of the existence of the disease in the Santa María Valley between the end of the Late Ceramic Period and the onset of the expansion of the Inca Empire (Arrieta et al. 2011). A further study described a case from the Nasca culture from southern Peru dating to about 900 AD (Lombardi \& Cáceres 2000). The authors concluded that there was a pandemic level of tuberculosis in the Southern Peruvian coast at this time. The population in Chile, studied by Arriaza et al. (1995), was also agricultural. All the skeletons analysed in their paper were dated to 500-1000 AD, which correlates with fully agricultural societies in this region. Agricultural societies are likely places to find tuberculosis because they generally have large populations of people living in close contact. Tuberculosis is a density-dependent disease (Barnes et al. 2011) that is generally only present in populations such as these.

High population density enables the transmission and maintenance of tuberculosis because it is transmitted between people via the inhalation of infected droplets coughed or sneezed from the lungs of an infected individual. Likelihood of infection therefore increases when people are living in close contact and the chance of the disease being maintained within the population is higher in larger populations (Donoghue 2009). Thus the discovery of tuberculosis in indigenous populations in the Americas provides us with interesting information about the size of these populations. They must have been sufficiently large for the disease to be maintained and 
the people must have been living in close contact to each other, in order for the disease to be transmitted.

M. tuberculosis has been found in North and South America, but strangely, concrete evidence of tuberculosis appears lacking in the ancient Mayan cultures of Mesoamerica. It is probable that the ancient Maya were infected with tuberculosis as their population size was sufficient, they had well established trade routes across the Americas that would have enabled the disease to spread and Mayan art displays individuals that have features characteristic of tuberculosis (Mackowiak et al. 2005). Possible reasons for this lack of evidence of tuberculosis have been discussed (Mackowiak et al. 2005, Wilbur \& Buikstra 2006). One explanation may be that persons suffering from tuberculosis were disposed of in a specific way after death that has not yet been discovered by modern archaeologists. Wilbur and Buikstra (2006) commented, however, on the very poor state of bone preservation in these remains that may have led to the lack of aDNA data. They also suggested that the particular M. tuberculosis genetic lineage in this population was less likely to disseminate from the lung into the bones. It should be noted that in any event, skeletal tuberculosis was extremely rare even in the pre-antibiotic era, with only around $3-5 \%$ of infections resulting in visible lesions (Resnick \& Niwayama 1995).

Souvenir human infectious diseases in the Americas - When humans first migrated to the Americas they found a landmass already inhabited by wildlife and their pathogens. Many microorganisms that originally infected American wildlife jumped the species barrier and adapted to enable them to cause zoonotic infections in humans. Examples based on historical material or modern genomic studies include bartonellosis or Carrión's disease (Allison et al. 1974a), mucocutaneous leishmaniasis (Costa et al. 2009), Lyme borreliosis (Margos et al. 2008), salmonellosis (Sawicki et al. 1976), toxoplasmosis (Lehmann et al. 2006) and treponematosis (Marden \& Ortner 2011). Two souvenir diseases are discussed below in more depth, as each gives insight into the environment where pathogens and indigenous peoples interacted.

T. cruzi - Human living conditions - Chagas disease exists in the Americas today from southern North America to southern Argentina and causes much human suffering. It is caused by the T. cruzi parasite. T. cruzi is one of the three major pathogens in the trypanosomatid group. The other pathogens of the group are Trypanosoma brucei that causes African sleeping sickness and Leishmania spp. The trypanosomatid group consists of very ancient eukaryotic flagellate protozoa of the Kinetoplastida order that have a single flagellum. Stevens et al. (1999) dated the divergence of T. cruzi and T. brucei to approximately one hundred million years ago, following the separation of the landmasses of Africa, South America and Euroamerica. T. cruzi and T. brucei have since evolved to become quite different pathogens.

Kinetoplastida are characterised by the presence of kinetoplast DNA near the flagellate's basal body. Kinetoplast DNA is an extra nuclear DNA network of circular molecules that corresponds to the parasite mitochondrial genome (Araújo et al. 2009). This kinetoplast DNA is ex- tremely useful in the identification of T. cruzi in ancient remains. Detection of the kinetoplast DNA is very sensitive due to the high copy number/cell (several thousand) and can readily be achieved by PCR amplification and detection via hybridisation with a probe (Guhl et al. 1999, Aufderheide et al. 2004). Evidence for T. cruzi can also come from the observation of ancient remains, as the disease can often result in morphological changes such as megacolon - enlargement of the colon (Guhl et al. 1999, Reinhard et al. 2003). Therefore, mummies have been essential to the diagnosis of $T$. cruzi via such morphological observations. Using such methods, ancient $T$. cruzi has been found in ancient human remains across the Americas from Northern Chile (Guhl et al. 1999) to central Brazil (Fernandes et al. 2008) to North America (Reinhard et al. 2003).

T. cruzi is transmitted between its vertebrate hosts via a triatomine insect vector. T. cruzi is a very heterogeneous parasite with many different genetic and phenotypic markers, indicating its great diversity. It infects many triatomine insects that act as a vector for parasite transmission between mammals. T. cruzi can infect nearly all the tissues of more than one hundred species of mammals. Indeed Llewellyn et al. (2011) revealed that even within a single mammalian reservoir, great diversity could often be present. Triatomine insects hide inside animal nests/human homes and extract blood from the host while it is sleeping. T. cruzi is present in the triatomine faeces, so when the insect bite causes itching the faeces are pushed into the bite wound and the parasite enters the bloodstream and causes infection. The parasite has very little effect on most feral American animals that it infects, suggesting that it has infected these animals for such a long time that they have evolved and adapted to live normally with it. The disease does however often cause premature death in humans, most often as a result of cardiac complications (Aufderheide et al. 2004). This indicates the more recent association of humans with this parasite and shorter time to adapt to living with the parasite, as compared to feral animals of the Americas.

Initially it was believed that humans first entered the T. cruzi life cycle in the Andean region when triatomine insects became domiciled after the development of urban populations, a sedentary lifestyle and animal domestication (Coimbra Jr 1988). However, it is now thought more likely that humans entered into the zoonotic cycle of $T$. cruzi very soon after entering the Americas (Ferreira et al. 2011) as research indicates that $T$. cruzi was infecting prehistoric indigenous populations long before the development of urban centres in the Andean region. The work of Aufderheide et al. (2004) revealed that T. cruzi has been infecting peoples of the Andean coast for at least 9,000 years and before the development of urban centres in the Andean region. Triatomine insects require some sort of nest to live in, so it may have been the straw bedding of indigenous nomadic populations that first led to humans coming into contact with this parasite. Indigenous urban populations often had houses of wattle and thatch that would again have been ideal nests for triatomine insects. Humans would have been a great new source of food for the triatomine insects and their living conditions, a great new place for protection from climatic changes and predators. 
Lima et al. (2008) used aDNA analyses to show that T. cruzi infected both ancient nomadic and urban indigenous peoples of the Americas. They detected T. cruzi human infection in Brazil dating back at least 4,500 years, in an individual from a hunter-gatherer population that preceded T. infestans domiciliation. The T. cruzi I genotype was demonstrated 4,500-7,000 years ago in the state of Minas Gerais, where this genotype is currently absent, suggesting that the distribution pattern of T. cruzi genotypes in humans has changed in time and place. T. cruzi I is widespread among wild mammals and sylvatic vectors of all biomes. This genotype is commonly isolated from humans and wild mammals in the Amazon Basin today. In contrast, T. cruzi II has a focal distribution in nature, but is the main agent of human infection in other Brazilian regions. Further understanding of the exact nesting conditions triatomine insects require may help us learn more about the living conditions of indigenous peoples of the Americas that first put them in contact with this insect.

Coccidioidomycosis - Human agricultural development - Coccidioidomycosis, also known as valley fever, is a non-communicable ascomycete fungal disease associated with desert-like areas. The disease is acquired via the inhalation of the spores of the fungus, which is found approximately $20 \mathrm{~cm}$ beneath the surface of the soil. Today C. immitis is found in the San Joaquin Valley, California. The closely related Coccidioides posadasii, also known as non-California C. immitis, has a wider distribution, being recovered from across the southwestern United States of America, southern California, northern, central and southern Mexico and South America (Fisher et al. 2002).

C. immitis goes through a saprophytic stage and a parasitic stage in its life cycle. The saprophytic stage is a very hardy mould phase that leads to the maturation of the hyphal cells into arthroconidia (rectangular spores). The parasitic phase begins when a human or animal inhales the arthroconidia. Once inside the host lungs the arthroconidia then enlarge to become spherules (spherical double-walled cells). Upon spherule rupture endospores are released that can disseminate in the host and re-initiate the spherulation cycle. This causes a disseminated form of the disease, in which the spherules enter the bloodstream and spread beyond the lungs. Disseminated coccidioidomycosis occurs particularly during pregnancy and is frequently fatal. However, in most cases of infection there are either no symptoms or only minor cold-like symptoms (Kolivras et al. 2001). Strict precautions have to be taken by individuals, such as archaeologists, who are at risk of becoming infected (Poirier \& Feder 2001).

C. immitis and C. posadasii are the only members of this genus capable of causing life-threatening disease in humans and other mammals. Other members of this family live predominantly as plant pathogens, so it is most parsimonious to assume that mammalian virulence was recently and uniquely acquired in Coccidioides (Sharpton et al. 2009). It is believed that the common ancestor of Coccidioides and non-pathogenic species likely grew on dead or decaying animal matter or on external surfaces of an animal host, such as hair. However, once this association with animals was established, the shift from plantbased to animal-based nutrition ultimately led to disease. The two Coccidioides species diverged 5.1 million years ago, well before humans arrived in the New World (Pitulko et al. 2004), so this evolutionary transition to a pathogenic phenotype probably involved mainly rodent hosts and not humans. Some animals, such as mice, now have genes that make them resistant to the disease, which has led to the suggestion that this reflects the prolonged period of time over which Coccidioides spp have infected feral American animals (Kirkland \& Fierer 1996).

Harrison et al. (1991) presented the first microscopic evidence of prehistoric human infection with Coccidioides. They identified human remains in Arizona dated to approximately 1000-1400 AD and therefore belonging to the Sinagua culture. Evidence that the individual had suffered from coccidioidomycosis included the presence of spherules (in the parasitic stage) preserved within the skeleton and the presence of massive widespread lesions suggestive of the disease. Contamination by the fungus after death was ruled out because of the presence of the lesions and the fact that all the fungi present were identified as being in the parasitic stage. This research was carried out before PCR was a widespread technique used in paleomicrobiology, so there were no DNA analyses carried out to confirm the diagnosis. Evidence of ancient coccidioidomycosis infection has also been reported by Temple (2006) in the Los Muertos site in Arizona, which is still an endemic region for coccidioidomycosis today. An ancient adult male of the Hohokum population was found in this region dated to approximately $1150 \mathrm{AD}$, with lesions suggestive of the disease. Again, the diagnosis is entirely based on the paleopathology of the skeletal lesions.

There was frequent soil contact in prehistoric Hohokum populations in this region because the region contained many irrigation canals that were used to support agriculture (Bayman 2001, Temple 2006). Significant construction efforts on the canals took place around the time that this human individual is approximately dated. Digging and maintaining these canals would have placed workers in direct contact with the soil that is the habitat of Coccidioides and therefore put workers at risk of infection. Given these circumstances, the fact that people still suffer from coccidioidomycosis in this area today and the skeletal lesions present on the individual, it appears likely that pre-colonial peoples of this region were infected with this fungus. In future, molecular evidence from aDNA analyses should be able to confirm this.

Analysis of microsatellite loci from C. immitis showed that genetic diversity in this fungus is geographically partitioned throughout North America (Fisher et al. 2001). In contrast, the South American C. immitis population appears to have originated from a single North American population centred in Texas. Genetic analyses show that South American C. immitis strains have undergone rapid population growth, consistent with an epidemic increase in post-colonisation population size. Fisher et al. (2001) estimated that the introduction into South America occurred within the last 9,000-140,000 years and noted that this increase in range parallels that of H. sapiens. They cited Lacy and Swatek (1974) who had noted that viable $C$. immitis was strongly associated with Amerindian middens in California and this appeared to be due to the soil alkalinity and past accumulation of domestic contaminants. Because of this, Fisher et al. (2001) suggest that the colonisation of South America 
by $C$. immitis represents a relatively recent and rapid codispersal of a host and its pathogen.

European contact with the Americas - What happened subsequent to European discovery of the Americas completely shifted the global distribution of human infectious diseases. Human infectious diseases had evolved independently in the Eastern and Western Hemispheres for thousands of years. Both Hemispheres were home to human populations in which hunting and gathering and the development of agriculture and urban centres were present, yet the geography, climate and native organisms in the hemispheres were different. For these reasons and because of simple chance, there were very different human infectious diseases present in the Eastern and Western Hemispheres (Merbs 1992, Camargo 1994). Europeans brought many fatal infectious diseases, including smallpox, measles and malaria, to the Americas that had not existed there before, so indigenous peoples of the Americas had no genetic resistance to them. In contrast, Europeans had developed high degrees of immunity to these diseases over the centuries they had been exposed.

The work of Barnes et al. (2011) shows that populations with a long history of urban settlement have greater genetic resistance to tuberculosis. However, another consequence of long-term urbanisation is the development of more virulent strains of pathogens, as transmission is more likely and a large population enables virulent pathogens to persist. This population effect is clearly demonstrated by examining the historical distribution of measles virus in insular communities, where the virus died out once all susceptible individuals had been infected only to recur after the virus was re-introduced (Black 1966). Such findings may explain why the Eastern Hemisphere, that has a longer history of urban settlement, contained more human infectious diseases and more virulent strains of some indigenous pathogens.

During the "period of exploration", a greater number of human infectious diseases were taken to the Americas from Europe than vice versa. In addition, considering post-colonial disease epidemiology, the indigenous peoples of the Americas represented a naïve population. The combination of infectious disease, displacement and warfare, brought to America by European colonialism, caused widespread devastation.

Paleomicrobiology is a fast developing area of research that can give us much interesting and useful biological, anthropological, historical and archaeological information. The microbial pathogens described in this review can illuminate the pre-colonial history of the indigenous peoples of the Americas, but raise more questions.

The work on $H$. pylori has provided information about human migrations into the Americas, but highlights the need for much more research. Further investigations should be carried out to consider how ancient human populations could have reached the Americas by sea. Investigating other heirloom infectious diseases in ancient human remains may also facilitate our understanding of migration into the Americas. Further research on $M$. tuberculosis, using hybridisation and DNA capture techniques, for example, may detect tuberculosis in cultures and sites, such as Mesoamerica, where evidence is currently lacking. Investigating which strains of M. tuberculosis are present in ancient human remains may tell us about ancient human migrations, but also help answer the question of whether indigenous American strains were significantly different from European strains. If European strains were more virulent this could explain why there was such devastation from tuberculosis post-contact. Research into T. cruzi and its insect vector should lead to greater understanding of the living conditions of the indigenous peoples of the Americas that first put them in contact with this insect and parasite. Molecular evidence is required to confirm the existing diagnoses of $C$. immitis and/or C. posadasii in the pre-Columbian Americas. Distinction between these two closely related fungi may yield interesting data on their ancient distribution in the environment.

The study of paleomicrobiology enables us to confirm paleopathological diagnoses and to answer historical questions about the extent and impact of human infectious diseases. As has been illustrated above, paleomicrobiology can provide evidence of ancient and historical migrations and indicate the living conditions of past populations. Paleogenomics also can provide real time calibration of genetic changes within pathogens and to link such changes with the society of their human hosts.

\section{REFERENCES}

Allison MJ, Mendoza D, Pezzia A 1973. Documentation of a case of tuberculosis in pre-Columbian America. Am Rev Respir Dis 107: 985-991.

Allison MJ, Pezzia A, Gerszten E, Mendoza D 1974a. A case of Carrión's disease associated with human sacrifice from the Huari culture of southern Peru. Am J Phys Anthropol 41: 295-300.

Allison MJ, Pezzia A, Hasegawa I, Gerszten E 1974b. A case of hookworm infestation in a pre-Columbian American. Am J Phys Anthropol 41: 103-106.

Anastasiou E, Mitchell PD 2013. Palaeopathology and genes: investigating the genetics of infectious diseases in excavated human skeletal remains and mummies from past populations. Gene 528: 33-40.

Araújo A, Ferreira LF 2000. Paleoparasitology and the antiquity of human host-parasite relationships. Mem Inst Oswaldo Cruz 95 (Suppl. I): 89-93.

Araújo A, Jansen AM, Reinhard K, Ferreira LF 2009. Paleoparasitology of Chagas disease - A Review. Mem Inst Oswaldo Cruz 104 (Suppl. I): 9-16.

Araújo A, Reinhard K, Ferreira LF 2008a. Parasite findings in archeological remains: diagnosis and interpretation. Quatern Int 180: 17-21.

Araújo A, Reinhard K, Ferreira LF, Gardner SL 2008b. Parasites as probes for prehistoric human migrations? Trends Parasitol 24: 112-115.

Araújo A, Reinhard K, Leles D, Sianto L, Iñiguez AM, Fugassa M, Arriaza B, Orellana N, Ferreira LF 2011. Paleoepidemiology of intestinal parasites and lice in pre-Columbian South America. Chungara 43: 303-313.

Arriaza B, Salo W, Aufderheide AC, Holcomb TA 1995. Pre-Columbian tuberculosis in northern Chile: molecular and skeletal evidence. Am J Phys Anthropol 98: 37-45.

Arriaza B, Standen V, Reinhard K, Araújo A, Heukelbach J, Dittmar K 2013. On head lice and social interaction in archaic Andean coastal populations. International Journal Paleopathology 3: 257-268.

Arrieta MA, Bordach MA, Mendonça OJ 2011. Tuberculosis precolombina en el noroeste argentino (NOA). El cementerio de Rincón Chico 21 (RCH 21), Santa María, Catamarca. Intersecciones Antro 12: 245-260. 
Ascunce MS, Fane J, Kassu G, Toloza AC, Picollo MI, Gonzáles-Oliver A, Reed DL 2013. Mitochondrial diversity in human head louse populations across the Americas. Am J Phys Anthropol 152: 118-129.

Atherton JC 2006. The pathogenesis of Helicobacter pylori-induced gastro-duodenal diseases. Annu Rev Pathol 1: 63-96.

Aufderheide AC, Salo W, Madden M, Streitz J, Buikstra JE, Guhl F, Arriaza B, Renier C, Wittmers LE, Fornaciari G, Allison MJ 2004. A 9,000-year record of Chagas disease. Proc Natl Acad Sci USA 101: 2034-2039.

Barnes I, Duda A, Pybus OG, Thomas MG 2011. Ancient urbanization predicts genetic resistance to tuberculosis. Evolution 65: 842-848.

Bayman JM 2001. The Hohokam of Southwest North America. $J$ World Prehist 15: 257-311.

Black FL 1966. Measles endemicity in insular populations: critical community size and its evolutionary implication. $J$ Theor Biol 11: 207-211.

Bos KI, Harkins KM, Herbig A, Gagneux S, Buikstra J, Stone AC, Krause $\mathrm{J}$ 2014. A preliminary evaluation of Mycobacterium tuberculosis genomes from the pre-contact New World using high throughput DNA sequencing. Am J Phys Anthropol 153 (Suppl. 58): 83.

Braun M, Cook DC, Pfeiffer S 1998. DNA from Mycobacterium tuberculosis complex identified in North American, pre-Columbian human skeletal remains. J Archaeol Sci 25: 271-277.

Brosch R, Gordon SV, Marmiesse M, Brodin P, Buchrieser C, Elglmeier K, Garnier T, Gutierrez C, Hewinson G, Kremer K, Parsons LM, Pym AS, Samper S, van Soolingen D, Cole ST 2002. A new evolutionary scenario for the Mycobacterium tuberculosis complex. Proc Natl Acad Sci USA 99: 3684-3689.

Camargo CA 1994. 1492 - The medical consequences. West J Med 160: 545-553.

Camorlinga-Ponce M, Perez-Perez G, Gonzalez-Valencia G, Mendoza I, Peñaloza-Espinosa R, Ramos I, Kersulyte D, Reyes-Leon A, Romo C, Granados J, Muñoz L, Berg DE, Torres J 2011. Helicobacter pylori genotyping from American indigenous groups shows novel Amerindian vacA and $\operatorname{cag} A$ alleles and Asian, African and European admixture. PLoS ONE 6: e27212.

Castillo-Rojas G, Cerbón MA, López-Vidal Y 2008. Presence of Helicobacter pylori in a Mexican pre-Columbian mummy. BMC Microbiol 8: 119.

Chan JZ-M, Sergeant MJ, Lee OY-C, Minnikin DE, Besra G, Pap I, Spigelman M, Donoghue HD, Pallen MJ 2013. Metagenomic analysis of tuberculosis in a mummy. N Engl J Med 369: 289-290.

Coimbra Jr CEA 1988. Human settlements, demographic pattern and epidemiology in lowland Amazonia: the case of Chagas disease. Am Anthropol 90: 82-97.

Costa MA, Matheson C, Iachetta L, Llagostera A, Appenzeller O 2009. Ancient leishmaniasis in a highland desert of northern Chile. PLoS ONE 4: e6983.

Daniel TM 2000. The origins and precolonial epidemiology of tuberculosis in the Americas: can we figure them out? Int $J$ Tuberc Lung Dis 4: 395-400.

Dittmar K 2009. Old parasites for a New World: the future of paleoparasitological research: a review. J Parasitol 95: 365-371.

Donoghue HD 2008. Molecular paleopathology of human infectious disease. In R Pinhasi, S Mays (eds.), Advances in human paleopathology, John Wiley \& Sons Ltd, Chichester, p. 147-176.

Donoghue HD 2009. Human tuberculosis - an ancient disease, as elucidated by ancient microbial biomolecules. Microbes Infect 11: 1156-1162.

Donoghue HD 2013. Insights into ancient leprosy and tuberculosis using metagenomics. Trends Microbiol 21: 448-450.

Drancourt M, Raoult D 2005. Palaeomicrobiology: current issues and perspectives. Nat Rev Microbiol 3: 23-35.

Falush D, Wirth T, Linz B, Pritchard JK, Stephens M, Kidd M, Blaser MJ, Graham DY, Vacher S, Perez-Perez GI, Yamaoka Y, Mégraud
F, Otto K, Reichard U, Katzowitsch E, Wang X, Achtman M, Suerbaum S 2003. Traces of human migrations in Helicobacter pylori populations. Science 299: 1582-1585.

Fernandes A, Iñiguez AM, Lima VS, de Souza SMFM, Ferreira LF, Vicente ACP, Jansen AM 2008. Pre-Columbian Chagas disease in Brazil: Trypanosoma cruzi I in the archaeological remains of a human in Peruaçu Valley, Minas Gerais, Brazil. Mem Inst Oswaldo Cruz 103: 514-516.

Ferreira LF, Jansen AM, Araújo A 2011. Chagas disease in prehistory. Ann Acad Bras Cienc 83: 1041-1044.

Fisher MC, Koenig GL, White TJ, San-Blas G, Negroni R, Alvarez IG, Wanke B, Taylor JW 2001. Biogeographic range expansion into South America by Coccidioides immitis mirrors New World patterns of human migration. Proc Natl Acad Sci USA 98: 4558-4562.

Fisher MC, Koenig GL, White TJ, Taylor JW 2002. Molecular and phenotypic description of Coccidioides posadasii sp. nov. previously recognized as the non-California population of Coccidioides immitis. Mycologia 94: 73-84.

Frías L, Leles D, Araújo A 2013. Studies on protozoa in ancient remains - A Review. Mem Inst Oswaldo Cruz 108: 1-12.

Gagneux S 2012. Host-pathogen coevolution in human tuberculosis. Phil Trans R Soc B 367: 850-859.

Gagneux S, DeRiemer K, Van T, Kato-Maeda M, de Jong BC, Narayanan S, Nicol M, Niemann S, Kremer K, Gutierrez MC, Hilty M, Hopewell PC, Small PM 2006. Variable host-pathogen compatibility in Mycobacterium tuberculosis. Proc Natl Acad Sci USA 103: 2869-2873.

Gentry G, Lowe M, Alford G, Nevins R 1988. Sequence analyses of herpesviral enzymes suggest an ancient origin for human sexual behaviour. Proc Natl Acad Sci USA 85: 2658-2661.

Gerszten E, Allison MJ, Maguire B 2012. Paleopathology in South American mummies: a review and new findings. Pathobiology 79: 247-256.

Ghose C, Perez-Perez GI, Dominguez-Bello M-G, Pride DT, Bravi CM, Blaser MJ 2002. East Asian genotypes of Helicobacter pylori strains in Amerindians provide evidence for its ancient human carriage. Proc Natl Acad Sci USA 99: 15107-15111.

Guhl F, Jaramillo C, Vallejo GA, Yockteng R, Cárdenas-Arroyo F, Fornaciari G, Arriaza B, Aufderheide AC 1999. Isolation of Trypanosoma cruzi DNA in 4,000-year-old mummified human tissue from northern Chile. Am J Phys Anthropol 108: 401-407.

Gutierrez MC, Brisse S, Brosch R, Fabre M, Omaïs B, Marmiesse M, Supply P, Vincent V 2005. Ancient origin and gene mosaicism of the progenitor of Mycobacterium tuberculosis. PLoS Pathog 1: e5.

Harper KN, Armelagos GJ 2013. Genomics, the origins of agriculture and our changing microbe-scape: time to revisit some old tales and tell some new ones. Am J Phys Anthropol 57: 135-152.

Harrison WR, Merbs CF, Leathers CR 1991. Evidence of coccidioidomycosis in the skeleton of an ancient Arizona Indian. $J$ Infect Dis 164: 436-437.

Hershberg R, Lipatov M, Small PM, Sheffer H, Niemann S, Homolka S, Roach JC, Kremer K, Petrov DA, Feldman MW, Gagneux S 2008. High functional diversity in Mycobacterium tuberculosis driven by genetic drift and human demography. PLoS Biol 6: e311.

Hershkovitz I, Donoghue HD, Minnikin DE, Besra GS, Lee OY-C, Gernaey AM, Galili E, Eshed V, Greenblatt CL, Lemma E, BarGal GK, Spigelman M 2008. Detection and molecular characterization of 9,000-year-old Mycobacterium tuberculosis from a Neolithic settlement in the Eastern Mediterranean. PLoS ONE 3: e3426.

i Prat JG, de Souza SMFM 2003. Prehistoric tuberculosis in America: adding comments to a literature review. Mem Inst Oswaldo Cruz 98 (Suppl. I): 151-159.

Iñiguez AM, Reinhard K, Gonçalves MLC, Ferreira LF, Araújo A, Vicente ACP 2006. SL1 RNA gene recovery from Enterobius 
vermicularis ancient DNA in pre-Columbian human coprolites. Int J Parasitol 36: 1419-1425.

Jiménez FA, Gardner SL, Araújo A, Fugassa M, Brooks RH, Racz E, Reinhard K 2012. Zoonotic and human parasites of inhabitants of Cueva de los Muertos Chiquitos, Rio Zape Valley, Durango, Mexico. J Parasitol 98: 304-309.

Kirkland TN, Fierer J 1996. Coccidioidomycosis: a reemerging infectious disease. Emerg Infect Dis 2: 192-199.

Kliks MM 1990. Helminths as heirlooms and souvenirs: a review of new world paleoparasitology. Parasitol Today 6: 93-100.

Kolivras KN, Johnson PS, Comrie AC, Yool SR 2001. Environmental variability and coccidioidomycosis (valley fever). Aerobiologia 17: $31-42$.

Lacy GH, Swatek FE 1974. Soil ecology of Coccidioides immitis at Amerindian middens in California. Appl Microbiol 27: 379-388.

Lehmann T, Marcet PL, Graham DH, Dahl ER, Dubey JP 2006. Globalization and the population structure of Toxoplasma gondii. Proc Natl Acad Sci USA 103: 11423-11428.

Leles D, Araújo A, Ferreira LF, Vicente ACP, Iñiguez AM 2008. Molecular paleoparasitological diagnosis of Ascaris sp. from coprolites: new scenery of ascariasis in pre-Columbian South America times. Mem Inst Oswaldo Cruz 103: 106-108.

Li H-C, Fujiyoshi T, Lou H, Yashiki S, Sonoda S, Cartier L, Nunez L, Munoz I, Horai S, Tajima K 1999. The presence of ancient human T-cell lymphotropic virus type I provirus DNA in an Andean mummy. Nat Med 5: 1428-1432.

Lima VS, Iñiguez AM, Otsuki K, Ferreira LF, Araújo A, Vicente ACP, Jansen AM 2008. Chagas disease in ancient hunter-gatherer population, Brazil. Emerg Infect Dis 14: 1001-1002.

Linz B, Balloux F, Moodley Y, Manica A, Liu H, Roumagnac P, Falush D, Stamer C, Prugnolle F, Van der Merwe SW, Yamaoka Y, Graham DY, Perez-Trallero E, Wadstrom T, Suerbaum S, Achtman M 2007. An African origin for the intimate association between humans and Helicobacter pylori. Nature 445: 915-918.

Llewellyn MS, Rivett-Carnac JB, Fitzpatrick S, Lewis MD, Yeo M, Gaunt MW, Miles MA 2011. Extraordinary Trypanosoma cruzi diversity within single mammalian reservoir hosts implies a mechanism of diversifying selection. Int J Parasitol 41: 609-614.

Lombardi GP, Cáceres UG 2000. Multisystemic tuberculosis in a preColumbian Peruvian mummy: four diagnostic levels and a paleoepidemiological hypothesis. Chungara 32: 55-60.

Mackowiak PA, Blos VT, Aguilar M, Buikstra JE 2005. On the origin of American tuberculosis. Clin Infect Dis 41: 515-518.

Marden K, Ortner DJ 2011. A case of treponematosis from pre-Columbian Chaco Canyon, New Mexico. Int J Osteoarchaeol 21: 19-31.

Margos G, Gatewood AG, Aanensen DM, Hanincová K, Terekhova D, Vollmer SA, Cornet M, Plesman J, Donaghy M, Bormane A, Hurn MA, Feil EJ, Fish D, Casjens S, Wormser GP, Schwartz I, Kurtenbach K 2008. MLST of housekeeping genes captures geographic population structure and suggests a European origin of Borrelia burgdorferi. Proc Natl Acad Sci USA 105: 8730-8735.

Merbs CF 1992. A new world of infectious disease. Am J Phys Anthropol 35 (Suppl. 15): 3-42.

Ortega YR, Bonavia D 2003. Cryptosporidium, Giardia and Cyclospora in ancient Peruvians. J Parasitol 89: 635-636.

Patrucco R, Tello R, Bonavia D 1983. Parasitological studies of coprolites of pre-Hispanic Peruvian populations. Curr Anthropol 24: 393-394.

Pitulko VV, Nikolsky PA, Girya EY, Balilyan AE, Tumskoy VE, Koulakov SA, Astakhov SN, Pavlova EY, Anisimov MA 2004.
The Yana RHS site: humans in the Arctic before the last glacial maximum. Science 303: 52-56.

Poirier DA, Feder KL 2001. Dangerous places: health, safety and archaeology, Greenwood Press, Westport, 264 pp.

Ramenofsky AF, Wilbur AK, Stone AC 2003. Native American disease history: past, present and future directions. World Archaeol 35: 241-257.

Raoult D, Reed DL, Dittmar K, Kirchman JJ, Rolain J-M, Guillen S, Light JE 2008. Molecular identification of lice from pre-Columbian mummies. J Infect Dis 197: 535-543.

Reinhard K, Fink TM, Skiles J 2003. A case of megacolon in Rio Grande Valley as a possible case of Chagas disease. Mem Inst Oswaldo Cruz 98 (Suppl. I): 165-172.

Resnick D, Niwayama G 1995. Osteomyelitis, septic arthritis and soft tissue infection: organisms. In D Resnick (ed.), Diagnosis of bone and joint disorders, WB Saunders, Edinburgh, p. 2448-2558.

Rothschild BM, Martin LD, Lev G, Bercovier H, Bar-Gal GK, Greenblatt C, Donoghue H, Spigelman M, Brittain D 2001. Mycobacterium tuberculosis complex DNA from an extinct bison dated 17,000 years before the present. Clin Infect Dis 33: 305-311.

Salo W, Aufderheide AC, Buikstra JE, Holcomb TA 1994. Identification of Mycobacterium tuberculosis DNA in a pre-Columbian Peruvian mummy. Proc Natl Acad Sci USA 91: 2091-2094.

Sawicki VA, Allison MJ, Dalton HP, Pezzia A 1976. Presence of Salmonella antigens in feces from a Peruvian mummy. Bull N Y Acad Med 52: 805-813.

Sharpton TJ, Stajich JE, Rounsley SD, Gardner MJ, Wortman JR, Jordar VS, Maiti R, Kodira CD, Neafsey DE, Zeng Q, Hung C-Y, McMahan C, Muszewska A, Grynberg M, Mandel MA, Kellner EM, Barker BM, Galgiani JN, Orbach MJ, Kirkland TN, Cole GT, Henn MR, Birren BW, Taylor JW 2009. Comparative genomic analyses of the human fungal pathogens Coccidioides and their relatives. Genome Res 19: 1722-1731.

Spigelman M, Lemma E 1993. The use of the polymerase chain reaction (PCR) to detect Mycobacterium tuberculosis in ancient skeletons. Int J Osteoarchaeol 3: 137-143.

Stevens JR, Noyes HA, Dover GA, Gibson WC 1999. The ancient and divergent origins of the human pathogenic trypanosomes, Trypanosoma brucei and T. cruzi. Parasitology 118: 107-116.

Swanston T, Haakensen M, Deneer H, Walker EG 2011. The characterization of Helicobacter pylori DNA associated with ancient human remains recovered from a Canadian glacier. PLoS ONE 6: e16864.

Temple DH 2006. A possible case of coccidioidomycosis from the Los Muertos site, Tempe, Arizona. Int J Osteoarchaeol 16: 316-327.

Tran T-N-N, Aboudharam G, Raoult D, Drancourt M 2011. Beyond ancient microbial DNA: nonnucleotidic biomolecules for paleomicrobiology. Biotechniques 50: 370-380.

Verano JW 1997. Advances in the paleopathology of Andean South America. J World Prehist 11: 237-268.

Wilbur AK, Buikstra JE 2006. Patterns of tuberculosis in the Americas - How can modern biomedicine inform the ancient past? Mem Inst Oswaldo Cruz 101 (Suppl. II): 59-66.

Wirth T, Meyer A, Achtman M 2005. Deciphering host migrations and origins by means of their microbes. Mol Ecol 14: 3289-3306.

Yamaoka Y, Orito E, Mizokami M, Saitou N, Kodama T, Osato MS, Kim JG, Ramirez FC, Mahachai V, Graham DY 2002. Helicobacter pylori in North and South America before Columbus. FEBS Lett 517: 180-184. 